\title{
Legitimate Peripheral Participation and Teacher Identity Formation Among Preservice Teachers in TESOL Practicums
}

\author{
Cheng-hua Hsiao ${ }^{1, *}$ \\ ${ }^{1}$ Department of Foreign Languages and Literature, National Ilan University, Yilan County, Taiwan (R.O.C) \\ *Correspondence: Department of Foreign Languages and Literature, National Ilan University, No.1, Shennong Rd., \\ Sec. 1, Yilan City, Yilan County 260, Taiwan (R.O.C.) Tel: 886-3-931-7890. E-mail: chhsiao@niu.edu.tw
}

Received: January 3, 2018

Accepted: February 11, 2018 Online Published: March 2, 2018

doi:10.5430/jct.v7n1p64

URL: https://doi.org/10.5430/jct.v7n1p64

\begin{abstract}
Teacher identity has been an important issue in teacher education because teacher identity influences teachers' professional development. However, little has been explored in preservice teachers' identity formation within the EFL context of language teaching. In this study, the early influence on EFL student teachers' identity formation in practicums was studied from the perspective of legitimate peripheral participation (Lave \& Wenger, 1991). Ten participants enrolled in the practicum courses of the four educational institutions, organized by the English department of a national university in northern Taiwan. The frameworks of the practicums at each school were analyzed and the results for each case study revealed contextual factors that support and weaken teachers' professional identities. Three features were identified in the student teachers' identity formation: (1) a hybrid space between formal teachers and student teachers, (2) adhering to the institutions' demands-progressing from the periphery to the center, and (3) struggling teacher identity. Based on the findings, relevant pedagogical implications are discussed to help L2 preservice teachers achieve success in practicums.
\end{abstract}

Keywords: practicum, legitimate peripheral participation, teacher Identity formation

\section{Introduction}

Much recent literature on teacher education stresses the importance of teacher identity (Freese, 2006; Hoban, 2007; Sachs, 2005). Shifting from a university program to the practicum setting, student teachers may experience anxiety and disquiet in order to adjust to a new environment. This period is understood as an intense identity alternation, a time when a workplace context causes a student teacher to form his/her professional identity. Further, identity changes may take place throughout a teacher's career as a result of interactions with broader communities.

Teacher identity is an important construct, which has received discussions for decades. Rodgers \& Scott (2008) proposed definitions for modern conceptions of identity: identity is shifting and involves meaning construction in manifold contexts with socio- cultural implications. Teacher identity is also regarded as a personal enrichment process. On this personal level, researchers see the shaping of teacher identity as reciprocal interactions between emotions and experience in teaching contexts (Geijsel and Meijers, 2005).

In Beijarrd's (1995) earlier research, he separated teachers' professional identity into three categories: disciplinary knowledge, interactions with students and teacher role conception. Beijaard, Verloop, and Vermunt (2000) defined a teacher's professional identity as having expertise in subject matter, pedagogy, and didactics. Beijaard, Meijer and Verloop (2004) defined four features of teacher's professional identity: dynamic identity, sub-identities, teacher agency and involvement of context (Beauchamp \& Thomas, 2011; Nagamine, 2012; Sfard \& Prusak, 2005; Varghese, 2006). However, there are no comprehensive pictures of language teacher professional identity since there is no identity description in bilingual or second language education.

The school-university collaboration provided the incentive and prospect for legitimate peripheral participation projects. Using crucial elements of Lave and Wenger (1991) theory "legitimate peripheral participation," the researcher can explain the transformation process in the practicum from merely learning in theory to learning in practice. Learning is not only considered as a socially-situated activity but also an apprenticeship in workplaces. Partially participated novices accrue a more clear idea of the workplace practices and prepare for an application of 
membership of the target community. However, the teacher education literature identifies the need to enhance preservice teachers' involvement in practicum settings, there are few examples in EFL contexts.

Practicum opportunities are occupation specific. College students often decide the practicum types based on majors or interests. Students often perceive practicums as a means and an opportunity to learn more about the work environment to develop their competencies. Zlotowski (1998) noted that since the 1980s, practicums in American higher education have increasingly garnered academic attention. Tan (2005) stated that the use of practicums as a pedagogy is not a new practice; it has been adopted by educators in diverse disciplines, such as business (Cord \& Clement, 2010; Tan, 2005), mathematics (Duke, 1999), geology (Mogk \& King, 1995), communications (Bush-Bacelis, 1998), clinical education (Kessler \& Phillippi, 2015; Snyder, 2016; Strandell-Lane et al., 2015), leisure (Fong et al., 2014; Ruhanen et al., 2013), psychology (Hatcher \& Lassiter, 2007), and physical education (Hodge, Davis, Woodard, \& Sherrill, 2002). There has been no exception of teacher education (Haigh\& Ward, 2004; Ryan, Toohey \& Hughes, 1996; Schulz, 2005).

Journal articles also evidence the popularity of this practice. In Taiwan, practicums gained popularity after the 2000s. Chen et al (2015) reported that many colleges and universities in Taiwan have introduced practicum courses. In 2013, a total of 9,200 courses were introduced; this number is seven times higher than that in the previous decade. Both national and private universities in Taiwan have included practicums either as formal courses or as a graduation criterion. In addition, the number of students participating in overseas practicums has been increasing. Many university departments in Taiwan adopt certain measures for practicum design. English majors in foreign languages departments in Taiwan are no exception and some of them are particularly interested in English language teaching as their practicum choice. However, student learning experiences in teaching practicum in this EFL context has not been fully investigated (Chien, 2016).

\subsection{Purpose of Study}

This study was interested in the identity formation in the practicum period between starting to be an English language teacher and completion of several months of practicum because this period is thought to be a promising change about the career decision. This paper looked into factors in which the professional identities of ten EFL student teachers were shaped in their six months of practicum in different school settings through the interaction through contextual lens.

We examined four educational institutes that partnered with a university in the northern Taiwan to provide practicum courses. Each institute established a framework for their practicum programs for this partnership. The teaching practices that each student experienced and how the student teachers' identities developed were investigated to understand the interplay of teaching, supervision, and identity struggle in the communities of practice. Using the Wenger's $(1998$, p.5) intrinsic components of learning, we raised two research questionsin this study:

(1) What were the school frameworks and student teachers' participation level?

(2) What characterized student teachers' identity formation?

\section{Literature Review}

\subsection{Lave and Wenger's Legitimate Peripheral Participation}

Practicum courses are social in nature. In this study, we conceptualized practicums as social participation because practicums involve teaching institutes, colleagues, and some activities in which student teachers participate.

As we documented participants' process of being members in the target communities, we analyzed participants' practicum experiences from the "legitimate peripheral participation" perspective of Lave and Wenger (1991) to the constructed identity. Legitimate peripheral participation comprises several key concepts. According to Lave and Wenger (1991), student teachers' preliminary participation is legitimately marginal. Learning occurs when participants act together within communities of practice, which include different people, activities, and practices. Lave and Wenger disagree with conventional theories that define learning as personal internalization and knowledge acquisition based on mental operation and knowledge internalization; rather, they focus on communities of practice. However, they suggested that "being peripheral" implies that there are multiple and less-engaged approaches for entering a target community. Changing perspectives is one of the features of legitimate peripheral participation because learners' learning progress, identity development, and formation of membership in social communities occur continually. Here, "being peripheral" proposes a dynamic access to sources for engagement, which justifies various forms of community membership. 
Legitimate peripheral participation also functions as an analysis from which to evaluate whether teacher identities were developed in this study. Through mutual reciprocation, newcomers observe and adapt to the communities of practice. From a broadly peripheral perspective, newcomers gradually identify what constitutes the culture of a community. Communities of practice have their own patterns and developmental cycles; they self-reproduce in a manner that the transformation of newcomers into old-timers becomes central or essential to the practice.

\subsection{Definition of Identity}

Identity can be defined as the distinctive features that someone has or the personal or social meanings people ascribe to themselves (Beijaard, 1995; Bilgrami, 2001; Olsen, 2008, Gee, 2001). Numerous studies (Bilgrami, 2001; Castells, 2004; Cote \& Levine, 2002; Kroger, 2006; Wenger, 1998) have emphasized identity in the context of the social environment. Varghese, Morgan, Johnston, and Johnson (2005) categorize two types of identity: identity in practice as well as in discourse. Identity in practice refers to the identity relating to a community, usually in practice and the process of individual identification/non-identification; identity in discourse denotes discursively constructed agency, mainly through language through reflexivity. Singh \& Richards (2006) and Vaghese et al. (2007) define that identity is constructed, maintained, and negotiated primarily through discourse. All in all, Rodgers \& Scott (2008) give the preeminent definition on modern conceptions of identity: ever-changing, relationships with others and involvement of meaning construction in multiple contexts with socio-cultural implications

\subsection{Teacher Identity}

A framework of teacher identity provides the notions of the way to be, to act and to comprehend the essence of teaching itself and teacher role in society (Sachs, 2005) because the significance of teacher identity is recognized because the objective of a teacher education program is to develop learners' teacher identity (Sachs, 2005; Van Huizen et al., 2005). The literature on teaching and teacher education reveals that teacher identity is influenced by some internal factor, such as emotion (Rodgers \& Scott, 2008; Van Veen \& Sleegers, 2006; Zembylas, 2003) and external factor, such as contexts (Flores \& Day, 2006; Rodgers \& Scott, 2008; Sachs, 2005). These understandings about identity are helpful, yet the definitions are hardly transformed into operations for research.

Beijaard, Meijer, \& Verloop (2004) listed the components of teacher identity formation: teaching as a meaningful experience, performing teaching-related acts, belonging to a teaching community and learning as a teacher. The school climate, learners' characteristics, the interactions with colleagues and of school administrators can all be factors in shaping a student or new teacher identity. Singh and Richards (2006) suggest that ideologies, discourses, and content play a role in teacher identity. Some literature suggests that teaching discipline may also affect identity (Varghese, Morgan, Johnston, Johnson, 2005). These formative contexts provide exposure and challenges for teacher identity (Coldron \& Smith, 1999).

Past studies note that teacher identity focused on preservice teacher in practicum (Addiego, 2013; Chong et al 2009; Conroy, 2012; Dang, 2013;; Garza-Reyna, 2011; He, P. \& Lin, A, 2013; Kanno\& Stuart, 2011; Nagamine, 2012; Nguyen, 2013), preservice teacher in a remedial project (Chien, 2016), graduate students in teacher education (Hung, 2008), undergraduate students in teacher education (Atkinson 2004; Friesen M. \& Besley S., 2013; Lim, 2011; Lin et al., 2012; Chong, Low \& Goh, 2011; Sutherland et al, 2005), new teachers at the boundary (Beauchamp C.\&Thomas L., 2011); new teachers in their beginning practices (1-3 years) (Ruohotie-Lyhty, 2013; Xu, 2012, 2013; Flores and Day, 2006) and formal teacher (Lasky S., 2005; Beijaard D.,Verloop N. \& Vermunt J., 2000; Søreide, 2006). In this study, the researcher intended to know how teacher identity is formed among tenpre-service teachers in their practicums, particular in the EFL profession, into order to fulfill the gap in the past literature.

\subsection{Studies in Preservice Teacher Identity}

Studies note that contexts play a critical role in the formation of student teachers' identity (Smagorinsky, Moore, Cook, Jackson, \& Fry, 2004). Preservice teachers' professional identity is developed through interactions with students and course content (Barnawi, 2010; Morgan, 2009) and the sense of reality is perceived during practicums. Previous research also suggests the student teachers accumulate reflections from the anxiety, interactions, and increased support from colleagues (Bullough et al., 2003; Dang, 2013; Nokes et al.). In Cattley's (2007) study, the preservice teachers raised issues such as team work, student commitment in learning tasks, solving discrepancies between parent and teachers' values and balancing the workloads, classroom managements. Chong et al. $(2009,2011)$ revealed that preservice teachers were preoccupied with identifying themselves as teachers. This sense of self is reconfigured in meaningful contexts to provide thematic stories of teacher identity before practicum. They tended to become more realistic in terms of their perception towards teaching after their teacher education program. In Walkington's (2005) study, the results documented most frequently was the realization about teacher workload and 
preparations outside the classroom. Given the existing and mounting importance, there has been little work done on the identities of student teachers, particularly in EFL contexts.

\subsection{Studies in Language Teachers' Identity in ESL or EFL Contexts}

Language teacher identity is an emergent focus in research on language teacher education and teacher development. Teacher identity in the ESL context is related to social and cultural contexts (Beijjard, Meijer, \&Verloop, 2004; Clarke, 2008; Cross, 2006; Miller, 2009; Varghese et al., 2005).

Student teachers revealed that they gained awareness of teacher-student roles and of their own identities as teachers through the hands-on teaching experience in the practicum and methods courses (Addiego's, 2013; Nagamine, 2012; Garzar-Reyna, 2011; Kanno and Stuart, 2011) The socio-cultural experience, the participants' interactions with students from varying linguistic, social, educational, and economic backgrounds, impacted their decisions regarding the roles they played in the process of being teachers.

Varghese, Morgan, Johnston, Johnson (2005) reported four themes in EFL and ESL contexts: marginalization, the status of nonnative speaker teachers, the position of language taught and the teacher-student relation. Varghese and Johnston (2007) depicted the evangelical Christians in EFL teaching context and these native speakers of English teachers embrace their religious belief in their English language teaching. Marginality and socio-economically disadvantaged minorities were particularly their teaching focus. In Santoro (1997) study, racist and gender were two factors in shaping their teacher identity.

Drawing on activity theory, He \& Lin (2013) conceptualized Lynn's practicum as a boundary-crossing between two altered activity systems: the school and the university communities. The tensions of the conflicting discourses impacted on Lynn's professional identity formation. Xu (2012) studied the transformation of novice ESL teachers' identities and concluded that novice teachers' initial cue-/exemplar-based imagined identities were transformed into rule-/schema-based ones influenced by the institutional contexts. Lim (2011) showed that factors such as career efficacy, English teacher role conception, and self-confidence altogether formed EFL student teacher identity.

Yet comparatively little concern has been expressed to language teachers' professional identity formation in Taiwan. It is understood that language teacher identity as a shifting and dynamic process which emphasizes the negotiation of one's own teaching beliefs and practices. Therefore, we attempt to investigate the identity formation process in the practicum in Taiwan, an EFL context where EFL teacher education is highly valued and Taiwanese preservice students'practicum experiences are less reported.

\section{Method}

\subsection{Data Collection}

\subsubsection{Participants}

The study was conducted during an 18-week spring semester in 2014 in the English department of a university in the northern Taiwan. A total of ten undergraduate students, majoring in English language and Western literature, volunteered to enroll in the practicum. According to the school regulations, each student teacher had to work at least eighty hours to gain a credit for this course.

\subsubsection{Practicum Recruitment Procedure}

First, the department offered a recruitment orientation to the student teachers. In the orientation, the four educational organizations participating in the practicum were introduced and their quotas for the number of student teachers and qualifications were announced and explained. The registered student teachers were required to complete an application form and provide their resumes for interviews arranged with their desired institutes. Before the practicum began, all student teachers were given a booklet to remind them of the behavior that they had to follow at their respective workplaces. The student teachers' insurance fees were covered by the department; their parents' signatures were also required on the permission form that informed them of the content of the practicum and its duration.

\subsubsection{Practicum Model}

Considering the students' academic activities in school, part-time placement of 1-3 days per week ranging over a semester was used. This placement has commonly been employed in teacher education practicums (Briggs, 1984). The setup chosen seemed to be highly dependent on the customs and practices of these educational institutions. The apprenticeship practicum defined by Ryan, Toohey, and Hughes (1996) was adopted, in which learning is regarded as participation in communities of practice. The on-site supervisor provided guidance to the student teachers, and the 
aims of the practicum was perceived as the students' command of appropriate practices and introduction into the workplace.

\subsection{Data Sources}

Data were drawn from reflection logs written by ten student teachers who participated in the practicum. Two interviews for each student teacher were conducted. The interviews were transcribed for analysis.

\subsection{Data Analysis}

The texts from the reflections logs and the interviews were read and analyzed by two TESOL professors, one being the researcher of this paper and the other an assistant professor in TESOL. The texts were read through and parts of the texts expressing similar thoughts were chosen and organized into four units for teacher identity formation.

In Wenger's opinion, four components "experience," "practice," "community" and "identity" are closely and mutually connected (1998, p.5). The first three categories "experience", "practice," and "community" are combined. Therefore, the teaching method, level and age of target students, institutional policy, mentor's instruction and administration involved were examined at language institutions for the school framework. In examining these aspects, we used a figure to represent the framework in each teaching community.

Participation level is central to point out the resource student teachers access in the teaching community. Participation level enhances student teachers' visions of how a teacher should do their work and how to do it in the workplace. Here, we used "mentor's guidance," "pedagogical training," "administrative involvement" and "classroom context" to derive the level of participation in the assigned tasks or work. "Mentor's guidance" refers to an experience teacher leading the novice teacher to get familiar with the teaching community and learn the pedagogy. "Pedagogical practice" means that student teachers observe classes and do the teaching demonstration at the end of the term. "Administrative involvement" means that the school involves student teachers to do certain administrative tasks. "Classroom context" refers to whether they were formal classes whether teaching and learning takes place. In addition, the level of participation is further divided into categories as high, mid and low level participation. "High" is decided as the four components are all included, "mid" three or two components and "low" one or none.

Table 1. Four Stages of Interpretative System for Journal Writing

\begin{tabular}{|c|c|c|}
\hline Stage & Definition & Example \\
\hline Report & $\begin{array}{l}\text { Describing: giving a factual recount } \\
\text { (not reflective) }\end{array}$ & $\begin{array}{l}\text { A reading material was presented to students, asking } \\
\text { students to form groups to explain the meanings } \\
\text { paragraph by paragraph. }\end{array}$ \\
\hline Refocus & $\begin{array}{l}\text { Considering; making simple } \\
\text { suggestions for alternative; making } \\
\text { plans for action; explaining, as in } \\
\text { cause and effect }\end{array}$ & $\begin{array}{l}\text { I talked to the supervisor about how I will conduct the } \\
\text { class. The supervisor told me the grammatical mistakes } \\
\text { that students tend to make. I incorporated the } \\
\text { supervisor's comments into my lesson plan. }\end{array}$ \\
\hline Analyze & $\begin{array}{l}\text { Interpreting events; making sense of a } \\
\text { situation or event; comparing and } \\
\text { evaluating }\end{array}$ & $\begin{array}{l}\text { From the teaching demonstration, I learned that it takes } \\
\text { great efforts to make preparations before class and tried } \\
\text { to make sure that the content of my lecture was correct } \\
\text { and to what they need. }\end{array}$ \\
\hline Reconceptualize & $\begin{array}{l}\text { Reworking views and ideas; stating a } \\
\text { teaching philosophy or vision; image } \\
\text { of teaching and teachers; insights into } \\
\text { how students think about themselves } \\
\text { as teachers; stating purpose of } \\
\text { education }\end{array}$ & $\begin{array}{l}\text { I readily recognize that the differences between a } \\
\text { student and a teacher. A teacher not only has to } \\
\text { understand the lesson he/she is going to teach, he/she } \\
\text { must do their best to make their students fully } \\
\text { understand their lectures. It takes long to sharpen one's } \\
\text { pedagogy. }\end{array}$ \\
\hline
\end{tabular}

For the formation of teacher identity, it refers to teacher's responsibility, what a teacher needs to do and how to do his/her work. In this study, I used Evans and Maloney's (1998) interpretative system for journal writing. Four stages of analysis of the journals were used to code the students'experiences and to reflect on their teaching and preparation to derive the characteristics of their teacher identity formation. 
1) Report-describe a situation, feeling or lesson;

2) Refocus-reviewing the situation by considering simple options, offering explanations and consequences, and making adjustments for advance action;

3) Analyze- comparing and contrasting previous and current experiences, evaluating the situation and its consequences

4) Reconceptualize- adjusting their views and ideas by stating their language teaching philosophy, pondering over a teacher identity and their classroom practices.

\section{Results}

With regard to the first research question-What were the school frameworks and student teachers' participation level? -We first outline the context of practicum programs and identified several aspects experienced by the student teachersin the four case studies in Table 2. In each school, four aspects as (1) mentor's instruction, (2) teaching methods, (3) interactions of target students, and (4) institutional policies are explicated and student teachers' reactions towards these elements are included.

Table 2. School Frameworks

\begin{tabular}{|c|c|c|c|c|}
\hline & School A & School B & School C & School D \\
\hline $\begin{array}{l}\text { Number of student } \\
\text { teachers }\end{array}$ & 3 & 4 & 2 & 1 \\
\hline $\begin{array}{l}\text { Mentor's } \\
\text { Instruction during } \\
\text { the class }\end{array}$ & Yes & Yes & Yes & $\begin{array}{c}\text { No } \\
\text { (social worker) }\end{array}$ \\
\hline Teaching method & $\begin{array}{l}\text { Flipped } \\
\text { classroom }\end{array}$ & $\begin{array}{l}\text { Communicative } \\
\text { Language } \\
\text { Teaching }\end{array}$ & $\begin{array}{c}\text { Total Physical } \\
\text { Response }\end{array}$ & $\begin{array}{c}\text { No specific teaching } \\
\text { method } \\
\text { After-class tutorial }\end{array}$ \\
\hline Target Students & $\begin{array}{c}\text { Junior high } \\
\text { school students }\end{array}$ & $\begin{array}{c}\text { Elementary school } \\
\text { students }\end{array}$ & $\begin{array}{l}\text { Very young } \\
\text { students }\end{array}$ & $\begin{array}{c}\text { Elementary school } \\
\text { students } \\
\text { (Socioeconomically } \\
\text { disadvantaged students) }\end{array}$ \\
\hline Institutional Policy & Class Placement & $\begin{array}{l}\text { English-only } \\
\text { policy }\end{array}$ & No & Test as the term ended \\
\hline
\end{tabular}

School A

School A is a public junior high school located adjacent to the student teachers' school. Two English classes were observed: Class 801 and Class 808 . Class 801 was a regular class consisting of 30 eighth graders whereas Class 808 had 15 students with excellent English proficiency and was therefore an advanced English placement class. The black area in Figure 1 denotes what the student teachers were exposed to in the practicum.

\section{School A}

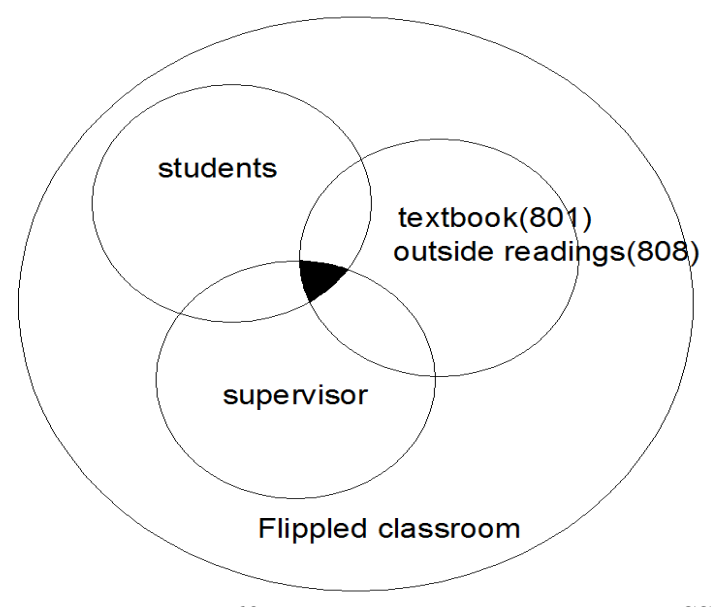


In School A, the student teachers reported that the mentor, Tony, promoted the concept and practices of a flipped classroom, which is also known as "learning, thinking, expressing (學思達)" in Taiwan. The student teachers unanimously agreed that this teaching method was effective in the English classrooms of this public junior high school; none of the children fell asleep or became distracted in the classroom; all children were attentive and prepared and eagerly awaited their turn to share their reports or small presentations with the class. They all paid close attention to the tasks assigned by the teachers.

However, for the first trial teaching, the student teachers' teaching performance failed to match the mentor's expectations. Table 3 was translated from one of the student teachers' reflections in which she compared the teacher's and student teachers' teaching methods.

Table 3. Contrast of On-Site Supervisor's and Student Teachers' Teaching Methods

\section{ON-SITE SUPERVISOR} FLIPPED CLASSROOM

\section{STUDENT TEACHER(ST) TRADITIONAL AND CRAMMED TEACHING METHOD}

While ST writes, students are asked to do nothing.

Unclear commands make students inattentive and lose concentrations.

ST dominated the class and students receive knowledge passively

ST gives grammar rule first, then ask students to make sentences(grammar $\rightarrow$ sentence examples)

On the other hand, the student teachers in School A witnessed that group behavior differed because of the placement effects. These three student teachers observed two classes: an advanced program (Class 801) and a regular program (Class 808). Class 801 comprised 16 students whose academic performance was within the top 15 . This advanced placement program provided students with current-affairs-oriented and news-oriented supplementary teaching materials; on the other hand, the regular program was textbook-oriented, following the school calendar. However, the classroom atmosphere in Class 801 was not lively. In analyzing the reasons, the three student teachers concluded that the learners in the advanced placement program were afraid of making mistakes and therefore they tended to be reserved for their answers. By contrast, the learners in the regular class were active and always prepared to share their opinions. Although they made occasional mistakes in expression, they enjoyed the classroom discussions and derived rules from many examples.

\section{School B}

School B is a chain cram school in which English is taught to children aged 3-15 years. They particularly welcomed student teachers who would be graduating in the summer to be formal teacher candidates. School B had four experienced supervisors guiding the student teachers in four classes. The student teachers were assigned five tasks, namely (a) observing supervisors' teaching classes and familiarizing themselves with teaching materials, (b) helping with administrative tasks, (c) correcting children's homework and conducting remedial classes, and (d) supporting gate reception, receiving phone calls, collection of tuition fees and ordering lunch boxes. Furthermore, the two senior student teachers were assigned trial teaching classes for kindergarten children.

School B had a standard of operation to maintain consistency in conducting all the classes that it offered. Each student was assigned a mentor, who was in charge of an English class. They were also required to teach at certain period of class time when their mentors felt they were able to do so. At various levels in School B, young learners experienced different activities, which resulted in gradual progresses in their English language acquisition. The final presentations of each semester revealed the outcomes of children's language development. In addition, the student teachers were amazed that the school followed an "English-only" policy. The student teachers identified with this policy because it was effective for communicating with the children as well as developing their English language proficiency levels. They used simple English to communicate in the English classrooms, and this policy was observed strictly by the teachers and children. English was used for various purposes, such as classroom management, teaching, and playing competitive games. Children seemed to comfortably adapt to this language 
learning environment.

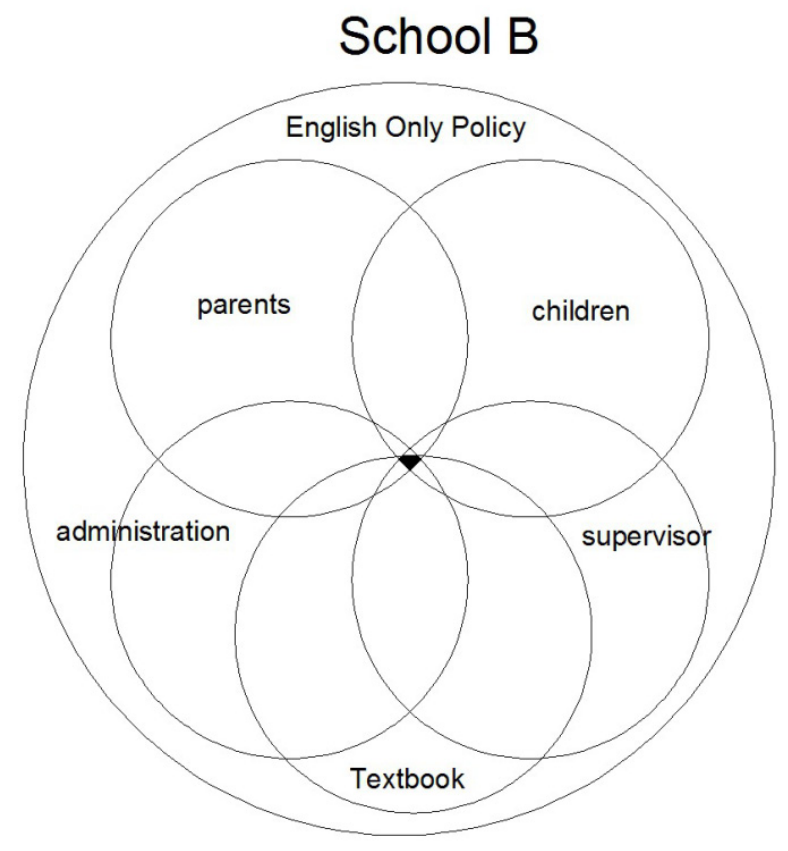

Figure 2. Community of School B

\section{School C}

School $\mathrm{C}$ is a kindergarten in which the children are aged 3-5 years. The principal promised two quotas for the student teachers to observe classes designed for preschoolers and conducted trial teaching during the semester. At School C, an experienced supervisor who taught preschoolers guided the two student teachers, using Total Physical Response (TPR).

\section{School C}

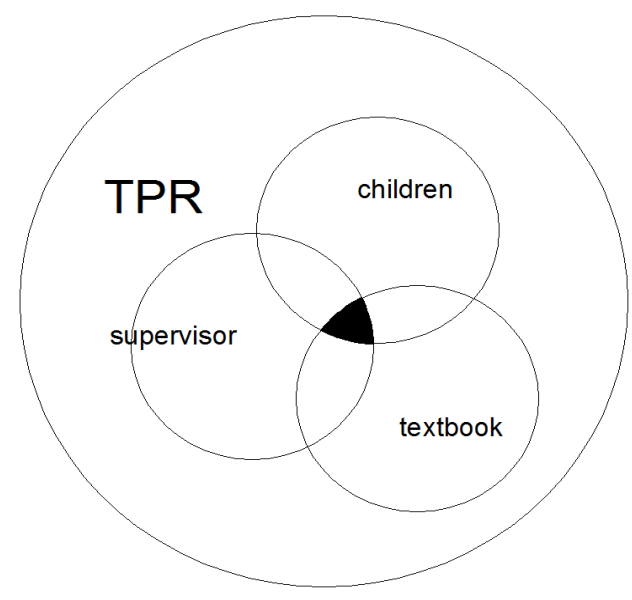

Figure 3. Community of School C

Two student teachers observed English classes under the supervision of the English teacher, Mandy, in School C. They were assigned to observe two classes per week for the first 3 months. Because they were more acquainted with the teaching techniques, Total Physical Response (TPR), they were able to teach one lesson to the young learners under the supervisor's guidance. 
They recognized that one of the salient differences between adult and children learners was attention span. The attention span of very young children was very short and, therefore, teachers had to use various techniques to retaintheir focus and interest. For example, because children are naturally receptive to sounds and images, the teachers used visual aids and chants to teach the children to identify with or internalize the pronunciation of letters or words. Moreover, during physical activities, acting, or games, the teachers sat on the ground in a circle to keep their height at the same level as the children's.

School D

School D is a charity program that aims to help socioeconomically disadvantaged children in remote areas because there were fewer educational resources for them. A charity education foundation offers the tutorial program, provides teacher education and recruits many college students to teach primary students. In addition to a socioeconomically disadvantaged status, the focal students of School D were judged by their schools as lagging in academics and misbehaving, and they came from different elementary schools in remote areas.

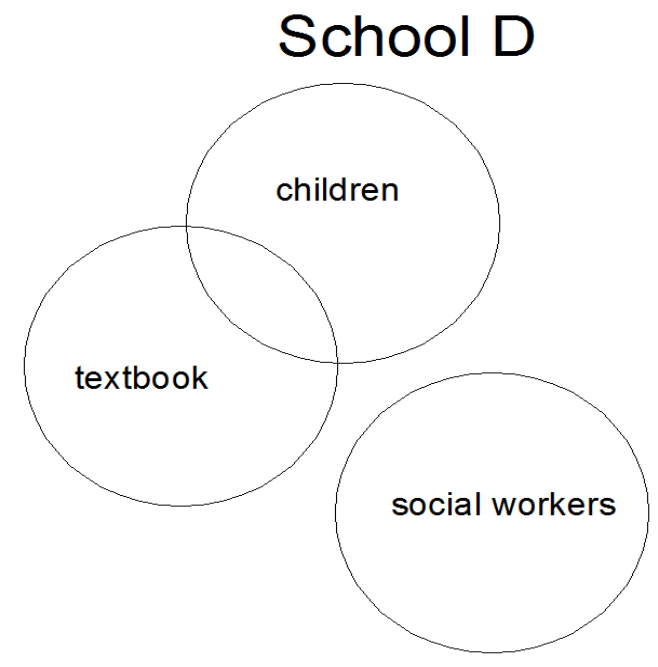

Figure 4. Community of School D

This education foundation has designed a series of English language teaching textbooks. One student teacher chose this project as her practicum. She was given an orientation on how to teach these academically-lagging-behind children by social workers before the project began. She was required to tutor certain units in the assigned textbook. After the tutorials, the three students she taught had to be tested for their achievements. The student teacher reported that most of the children were antisocial and disruptive because of family backgrounds and the psychology of bullying and being bullied. She followed the textbook to build up their English knowledge from pronunciation of English letters to basic vocabulary. However, there was no definite teaching method. She had to come up with her own ideas to teach them.

After introducing the four schools where the student teachers did their practicum, Table 4 shows the level of participation that these student teachers' accessed in four schools: (1) mentor's guidance, (2) pedagogical practice, (3) administrative involvement, (4) classroom context.

Table 4. Participation Levels at Four Schools

\begin{tabular}{lcccc}
\hline Schools & A & B & C & D \\
\hline Mentor's guidance & V & V & V & X \\
Pedagogical training & V & V & V & V \\
Administrative involvement & X & V & X & X \\
Classroom context & V & V & V & X \\
Participation Level & Mid & High & mid & low \\
\hline
\end{tabular}


In Table 4, it was found that the orientations into School A, B, C were with mentors' guidance. There were pedagogical trainings in three schools, A, B, and C. Only School B involved student teachers with administrative affairs. There was no real classroom context at School D because it was a tutorial program and no formal classes were observed and demonstrated in the program.

From this perspective, School B offered many educational resources for student teachers to access. School A and C lack of administrative involvement and School D only provided the student teachers with pedagogical practice. In this way, the participation levels vary among these four schools, ranging from high to low. School B provided most educational means for student teachers to access, termed as high participation level while School D provided least resources as low. School A and School C were rated as mid-level participation.

Participation level served as a conceptual means to examine the student teachers' involvement in understanding a teacher's practice and leads us to think about hidden themes and the dynamic and shifting relationships in the understandings of the workplace. School A and C seem to offer instruction participation: supervisors see community participation as a means of the efficient use of the skills and knowledge of community members in course implementation while School B seems to be a full participation, which gives the peripheral members diverse tasks in the implementation process of plans or guidelines that effects them to become an autonomous and independent teacher. The level of participation in School D is lowest because the student teacher accessed very few educational resources in her teaching community except using the textbook to teach the target students.

\subsection{Teacher Identity Formation}

In response to the second research question - what characterized student teachers' identity formation? We delineated the following three points from their accounts: a hybrid space between formal teachers and student teachers, adhering to the institutions' demands- progressing from the periphery to the center, and struggling teacher identity.

\subsection{A Hybrid Space between Formal Teachers and Student Teachers}

Although these student teachers had partially become teachers (student teachers), they knew that they were not as competent as their experienced supervisors. In School B, the student teachers reported that they had to wear "intern" name tags around their necks. The children asked them the meaning of "intern" and presented additional questions around this topic. Name tags helped reduce their anxiety because they showed a hybrid space between formal teachers and student teachers. At this stage, these novice student teachers were extremely sensitive about their teacher identity and their images in front of their students whether they were qualified as an English teacher.

The children in School A continued to address them as "teacher" instead of calling their English names and greeted them wholeheartedly or waved goodbye before leaving the school. These behaviors give student teachers some assurances that their presence won children notice and acknowledgement. The same case happened in School C (the kindergarten) was that when the mentor introduced the student teachers to the preschoolers as teachers, the term "teacher" was pronounced more loudly than it should have been. As the children sat in a semicircle, the student teacher sat behind the circle and observed how the on-site supervisor conducted the class. Some children would turn around to see her and sometimes asked for help when they were completing textbook exercises. The student teacher felt needed because she was not a nobody sitting at the back of classroom. The children acknowledged her presence and realized that she was a competent person who was able to offer them help.

\subsection{Adhering to Institution's Demands: Progressing from the Periphery to the Center}

Since student teachers recognized the learners' characteristics and institutions' policies, each student teacher adapted more to the institutions' pedagogical demands in order to develop their teachers' identities. By adhering to institution's demands at each school setting, these student teachers progress from the periphery to the center and learn to be a teacher.

In School A, the three student teachers, after they finished their teaching demonstrations, stated in their logs that junior high school students met on the hall way and called them "teachers" hence after. Particularly, one of student teachers felt relieved because the thought that she was not a formal teacher and that students were not willing to pay attention to her had disappeared. This is the first time she felt that she acted as a teacher and thought as a teacher. She had to care more about the effects of her teaching and student's learning.

As she wrote,

From the teaching demonstration, I learned that it takes great efforts to make preparations before class and tried to make sure that the content of my lecture was correct and to what they [the students] need. I readily recognize that the 
differences between a student and a teacher. A teacher not only has to understand the lesson he/she is going to teach, he/she must do their best to make their students fully understand their lectures. It takes long to sharpen one's teaching skills.

In School B, all the student teachers felt that following the English-only policy was a relatively daunting experience. They would pay extra attention to the classroom English and absorbed as many teaching techniques as they could to perform interactive teaching with the children while observing the classes. In the 20-minute trial lessons, they prepared all the teaching materials in advance, taking notes the English sentences they would say during each stage of the classes and took advantage of games to reinforce their learners' memory. One of the student teachers felt that she was gaining her teaching competency and the English-only policy pushed her to act more professionally. Under this policy, she was trained to use English as the classroom language to interact with the target students.

In School C, the student teachers learned about the process of teaching very young learners, which was completely different from the methods used in colleges. The student teachers had to recognize and consider students' emotions as well as focus on their pronunciation. Total Physical Response (TPR) was a method frequently used in the classrooms. In her trial teaching, one of the student teachers wrote a lesson plan on food and made the flash cards on her own. She introduced several new words for students to learn such as hamburger, sandwiches, spaghetti, soup, cake, and so on and led children to practice two sentence patterns: Would you like ? Yes, please. / No, thank you. Using the techniques she learned in observed classes, she successfully directed students to pronounce new words correctly and memorize the words when reading the flash cards. She gained sense of achievement and were happy that she grasped the teaching techniques to guide the very young learners to learn English alphabets and vocabulary.

From student teachers' reports and the researcher's observations, it was found that by adhering to institution demands, student teachers were progressing from the periphery to the center, both physically and mentally. They learned the techniques under a particular approach in each school setting, prepared the contents in advance under mentors' guidance and performed it in the trail teachings. The preparations and teaching demonstrations contributed to their teacher formations.

Further, most of them realized that when they stood in front of the class, they played the role of teachers; the children were under their guidance and they had to quickly learn certain teaching techniques that they had observed in the previous weeks to be a competent English teacher. They had to be a teacher instead of being an assistant or an older sibling. They were no longer in the peripheral position. Instead, they were in the center of the stage, acting the teacher role.

\subsection{Struggling Teacher Identity}

Among the four cases, the student teacher at School D received challenges from many facets. In the case of School D, certain students questioned the student teacher about her role as a formal teacher and showed reluctance to cooperate in the classes. They constantly challenged the student teacher's authority and behaved disruptively. This student teacher stated that she believed in using "tender, soft power" to educate students. However, this teaching philosophy was ineffective among this group of students. The student teacher experienced identity crisis and went to the program social worker (educational foundation) and school advisor (her own university) for advice.

These children were not willing to learn in any course and rejected any role that was associated with teaching or guidance. The student teacher reported the following:

"A school boy yelled at me, shouting 'Get out, teacher.' Because they knew that I was an intern, they did not want to listen to me and always said something bad in front of me. My weakness was that I did not have adequate authority to ask students to listen to me."

The student teacher was shocked and emotionally hurt because she did not know how to manage these students. Every class meeting was a disaster and a psychological struggle between giving up and continuing. In her case, her participation level was low. There are various contextual factors that caused her teacher identity vague and unclear-lack of real classroom contexts, absence of mentor's guidance, and short of students' acknowledgment. Before she taught those students, she was not formally introduced to the students and she had no information of students' mentality, family background and behavior patterns in the classrooms. In the four cases presented above, we can conclude that, at the stage of practicum, student teachers' identity is growing but full of struggles. 


\section{Discussion and Conclusuons}

\subsection{Level of Participation Embedded in Communities of Practice}

The purpose of communities of practice in this study is to provide a teaching method- practicum- for practitioners to share tips, appropriate practices and support for student teachers. For the student teachers in this study, the mentors were the on-site supervisors who provided guided participation, demonstrated the teaching methodology, and assigned certain teaching tasks. The guided participation involves other communities of practices, which constitutes different levels of participation. For School A and School C, they simply provided teaching methodology for student teachers to observe and replicate. In contrast, there are many layers of learning in School B. The student teachers not only learned the particular teaching methodology but also engaged with the administrative tasks. The student teachers were also paid hourly and were encouraged to be a part-time teacher after the practicum came to the end. They were exposed more to the education management of a language school and were forced to think about English teaching as one of their career options. Levels of participation show the educational resources that students can access. With more accesses of educational resources, student teachers can move from periphery to the center.

From this perspective, School D provided no such participation. The school's administration comprised social workers who could not provide genuine and immediate academic consultation and tacit knowledge in classrooms. Therefore, when the student teacher in School D experienced substantial difficulties in obtaining knowledge about the teaching methodology, identifying the socioeconomically disadvantaged children's characteristics, and maintaining relationships with those learners, she felt confused and hopeless. Although her teaching competence was developing, without proper guided participation, her teacher identity was somewhat vague. Without appropriate connections to a social network with experienced teachers' guidance in the teaching context, her membership in the teaching community did not emerge explicitly.

\subsection{Mastery of Community of Practice for Identity Formation}

The formation of teachers' identity requires a link between the knowledge base and the social context in which the knowledgeis applied (de Freitas, 2006). The TESOL practicum, which was considered workplace learning in this study, shaped novice teacher's professional identity. Based on the results, the ability to apply teaching methods under mentor's instruction, to adapt to institutions' policies across curriculums, and to have positive interactions with the target learners in real classroom contexts are recognized as factors of teachers' identity formation in their respective community practices. The above factors allow student teachers to directly observe on-site supervisors' teaching practices, rather than merely hearing about it secondhand in a lecture in the university, as well as to understand the manner in which tasks are managed and personally interact with target students in each class meeting. Thus, when student teachers master communities of practice, they progress from the periphery to the center of the workplace and fulfill the requirements of the teaching profession.

\section{Study Limitations and Implications}

The research has underscored the interaction from the contextual influences in the workplace learning. This study shows the efficacy of workplace factors on teacher identity formation. The identities of the novice teachers in this research had been strongly personally embedded in the teaching contexts. The influence of workplace played a key role in shaping student teachers' understanding of language instruction, in assisting or thwarting their professional learning and development, and in constituting their teacher identities. It is clear that in most, if not all cases, teacher's professional identity was mediated by context.

However, we suggest that more cases be observed because this study was restricted to only four case studies in a TESOL program in Taiwan. Moreover, supervisors' perspectives toward student teachers' identity development could be further investigated and cross-referenced. Moreover, the degree of administrative involvement, the perspective of mentors' perspectives should be explored at the same time to provide more information about teacher identity formation. We also hope that further investigation is conducted on longitudinal studies in order to know the change in teacher identity at different stages of development. Furthermore, how student teachers resolve their psychological struggles in the practicum process emerging during the internal operation of communities of practice can also be scrutinized in a wider context.

\section{References}

Addiego, E. S. (2013). The first year: Development of preservice teacher beliefs about teaching and learning during year one of an MA TESOL program (Unpublished master's thesis). Portland State University. 
Atkinson, D. (2004) Theorizing how student teachers form their identities in initial teacher education. British Educational Research Journal, 30(3), 379-394. https://doi.org/10.1080/01411920410001689661

Barnawi, S. (2010). Pedagogical tasks for fostering critical transformative EFL teachers: Pre-service EFL teacher educators. The Journal of International Social Research, 3(14), 107-118. https://doi.org/10.1080/136455700405208

Beauchamp C., \& Thomas L. (2011). New teachers' identity shifts at the boundary of teacher education and initial practice. International Journal of Educational Research, 5, 6-13. https://doi.org/10.14303/er.2014.012

Beijaard D. (1995). Teachers' Prior Experiences and Actual Perceptions of Professional Identity. Teachers and Teaching, 1(2), 281-294. https://doi.org/10.1080/1354060950010109

Beijaard, D., Meijer, P., \&Verloop, N. (2004). Reconsidering research on teachers' professional identity. Teaching and Teacher Education, 20 (2), 107-128. https://doi.org/10.1016/j.tate.2004.05.001

Beijaard, D., Verloop, N., \& Vermunt, J.D. (2000). Teachers' perceptions of professional identity: An exploratory study from a personal knowledge perspective. Teaching and Teacher Education, 16, 749-764. https://doi.org/10.1016/S0742-051X(00)00008-1

Bilgrami, A. (2001). Identity and identification: Philosophical aspects. In Smelser, Neil J., and Baltes, Paul B. (eds.), International Encyclopedia of the Social \& Behavioral Sciences. Amsterdam: Elsevier Science, 7148-7154. https://doi.org/10.1016/B978-012444562-8/50000-8

Briggs, F. (1984). The organization of practicum- the responsibilities of the teacher and the college supervisor: A pilot study. Australian Journal of Teaching Practice, 4(2), 15-26. https://doi.org/10.1177/000494417401800303

Bullough, R., Young, J., Birrell, J., Clark, D., Egan, M., Erickson, L., \& Welling, M. (2003). Teaching with a peer: A comparison of two models of student teaching. Teaching and Teacher Education, 19(1), 57-73. https://doi.org/10.1016/S0742-051X(02)00097-5

Bush-Bacelis, J. (1998). Innovative pedagogy: Academic service-learning for business communication. Business Communication Quarterly, 61(3), 20-34. https://doi.org/10.1177/108056999505800101

Castells, M. (2004). The Power of Identity ( $2^{\text {nd }}$ ed.). Malden: Blackwell Publishing.

Cattley, G. (2007). Emergence of professional identity for the pre-service teacher. International Education Journal, 8(2), 337-347. https://doi.org/10.5539/ies.v8n2p231

Chen, Y., Jan. S., \& Huang W. (2015). Survey and analysis on practicum in Taiwan universities. Evaluation Bimonthly, 54, 1-10. https://doi.org/10.1111/j.1751-0813.1972.tb05164.x

Chong, S., \& Low, E. (2009). Why I want to teach and how I feel about teaching-formation of teacher identity from pre-service to the beginning teacher phase. Educational Research for Policy and Practice, 8(1), 59-72. https://doi.org/10.1023/A:1021108703162

Chong, S., Low, E., \& Goh, K. (2011). Emerging professional teacher identity of pre-service teachers. Australian Journal of Teacher Education, 36(8), 50-64. https://doi.org/10.14221/ajte.2011v36n11.7

Chien, C. (2016). Pre-service English teachers' professional identity construction through lesson design and delivery of English remedial education. Journal of Teacher Education and Professional Development, 9(1), 1-26. https://doi.org/10.1007/s10857-006-9002-z

Clarke, A. (1995). Professional development in practicum settings: Reflective practice under scrutiny. Teaching and Teacher Education, 11(3), 243-261.

Clarke, M. (2008). Language Teacher Identities: Co-constructing Discourse and Community. Tonawanda, NY: Multilingual Matters.

Cochran-Smith, M., \& Lytle, S. (1999). Relationships of knowledge and practice: Teacher learning in communities. Review of Research in Education, 24, 249-305. https://doi.org/10.3102/0091732X024001009

Coldron J., \& Smith R. (1999). Active location in teachers' construction of their professional identities. Journal of Curriculum Studies, 31(6), 711-726. https://doi.org/10.1080/002202799183331

Conroy, K. N. (2012). Learning to teach and teaching to learn: The experience of nonnative speaking student teachers (Unpublished doctoral dissertation). University of Texas at Austin.

Cord, B., \& Clements M. (2010). Pathway for student self-development: A learning orientated internship approach. 
Australian Journal of Adult Learning, 50(2), 287-307. https://doi.org/10.1177/07417130022086955

Cote, J., \& Levine, C. (2002). Identity, Formation, Agency, and Culture: A Social Psychological Synthesis. Mahwah, NJ: Lawrence Erlbaum Associates.

Cross, R. (2006). Identity and language teacher education: The potential for socio cultural perspectives in researching language teacher identity. Paper presented at the Annual Conference of the Australian Association for Research in Education, Adelaide, Australia.

Dang, T. (2013). Identity in activity: Examining teacher professional identity formation in the paired-placement of student teachers. Teaching and Teacher Education, 30, 47-59. https://doi.org/10.1016/0742-051X(89)90018-8

De Freitas, S. (2006). Learning in Immersive Worlds. London: Joint Information Systems Committee.

Dewey, J. (1938). The Theory of Inquiry. New York: Holt, Rinehart \&Wiston.

Duke, J. (1999). Service learning: Taking mathematics into the real world. The Mathematics Teacher, 92(9), 794-796. https://doi.org/10.1111/j.1949-8594.1992.tb12175.x

English, R., \& Duncan-Howell, J.(2008). Facebook goes to college: Using social networking tools to support students undertaking teaching practicum. Journal of Online Learning and Teaching, 4(4), 596-601. https://doi.org/10.3167/latiss.2011.040101

Evans G., \& Maloney C. (1998). An analysis framework for reflective writing. Australian Journal of Teacher Education, 23(1), 29-39. https://doi.org/10.14221/ajte.1998v23n1.1

Flores, M., \& Day, C. (2006). Contexts which shape and reshape new teachers' identities: A multi-perspective study. Teaching and Teacher Education, 22(2), 219-232. https://doi.org/10.1016/j.tate.2004.11.001

Fong, L., Luk, C., \& Law, R. (2014). How do hotel and tourism students select practicum employers? A segmentation approach. Journal of Hospitality, Leisure, Sport \& Tourism Education, 15, 68-79. https://doi.org/10.3794/johlste.21.23

Freese, A. (2006). Reframing one's teaching: Discovering our teacher selves through reflection and inquiry. Teaching and Teacher Education, 22, 110-119. https://doi.org/10.1016/j.tate.2005.09.008

Friesen M., \& Besley S. (2013). Teacher identity development in the first year of teacher education: A developmental and social psychological perspective. Teaching and Teacher Education, 36, 23-32. https://doi.org/10.1016/0742-051X(89)90018-8

Garza-Reyna, G. (2011). Why did I become a teacher? Using written narratives to explore the sociocultural influences affecting the preservice, elementary teacher's decision to enter the field of education. Journal of Border Educational Research, 10, 40-51. https://doi.org/10.1080/00220671.1924.10879483

Gee, J.P. (2001). Identity as an analytic lens for research in education. Review of Research in Education, 25, 99-125.

Geijsel, F., \& Meijers, F. (2005). Identity learning: The core process of educational change. Educational Studies, 31(4), 419-430. https://doi.org/10.1207/s15326993es0504_2

Haigh, H. \& Ward, G. (2004). Problematising practicum relationships: Questioning the "taken for granted." Australian Journal of Education, 48(2), 134-148. https://doi.org/10.1177/000494410404800101

Hatcher, R., \& Lassiter, K. (2007). Initial training in professional psychology: The practicum competencies outline. Training and Education in Professional Psychology, 1(1), 49. https://doi.org/10.1037/tep0000137

He, P., \& Lin, A. (2013). Tensions in school-university partnership and EFL pre-service teacher identity formation: A case in mainland China. The Language Learning Journal, 41(2), 205-218. https://doi.org/10.1080/09571739085200161

Hew, K., \& Knapczyk, D. (2007). Analysis of ill-structured problem solving, mentoring functions, and perceptions of practicum teachers and mentors toward online mentoring in a field-based practicum. Instructional Science, 35(1), 1-40. https://doi.org/10.1007/BF00051902

Hoban, G. (2007). Considerations for designing coherent teacher education programs. In J. Butcher \& L. McDonald (Eds.), Making a difference: Challenges for teachers, teaching and teacher education (pp. 173-187). Rotterdam: Sense Publishers. https://doi.org/10.1016/0742-051X(92)90010-Z

Hodge, S., Davis, R., Woodard, R., \& Sherrill, C. (2002). Comparison of practicum types in changing preservice teachers' attitudes and perceived competence. Adapted Physical Activity Quarterly, 19(2), 155-171. 
https://doi.org/10.1123/apaq.19.1.114

Hung, H. (2008). Teacher learning: Reflective practice as a site of engagement for professional identity construction. US-China Education Review, 5(5), 39-49. https://doi.org/10.1080/0098559790050101

Kanno, Y., \& Stuart, C. (2011). Learning to become a second language teacher: Identities-in-practice. The Modern Language Journal, 95(2), 236-252.https://doi.org/10.1111/j.1540-4781.2011.01181.x

Kessler, J., \& Phillippi, J. (2015). Incorporating a primary care practicum in midwifery education. Journal of Midwifery and Women's Health, 60(3), 258-262. https://doi.org/10.1016/j.jmwh.2005.08.016

Kolb, D. (1984). Experiential learning: experience as the source of learning and development. New Jersey: Prentice-Hall.

Kroger, J. (2006). Identity development: Adolescence through adulthood. Thousands Oaks, California: Sage publications.

Lasky S. (2005). A sociocultural approach to understanding teacher identity, agency and professional vulnerability in a context of secondary school reform. Teaching and Teacher Education, 21(8), 899-916. https://doi.org/10.1016/j.tate.2004.11.001

Lave, J., \& Wenger, E. (1991). Situated learning: Legitimate peripheral participation. New York: Cambridge University Press.

Lim, H. (2011). Concept maps of Korean EFL student teachers' autobiographical reflections for their professional identity formation. Teaching and Teacher Education, 27(6), 969-981. https://doi.org/10.1016/j.tate.2010.10.011

Lin, W., Shein, P., \& Yangi, S. (2012). Exploring personal EFL teaching metaphors in pre-service teacher education. English Teaching: Practice and Critique, 11(1), 183-199. https://doi.org/10.1108/etpC-04-2015-0032

Malderez, A., Hobson, A., Tracey, L., \& Kerr, K. (2007). Becoming a student teacher: Core features of the experience. European Journal of Teacher Education, 30(3), 225-248. https://doi.org/10.1080/02619760701275578

Miller, J. (2009). Teacher identity. In A. Burns. \& J. C. Richards. (Eds.), The Cambridge guide to second language teacher education (pp. 172-183). New York, NY: Cambridge University Press. https://doi.org/10.1093/elt/ccr006

Mogk, D., \& King, J. (1995). Service learning in geology classes. Journal of Geological Education, 43(5), 461-465.

Morgan, B. (2004). Teacher identity as pedagogy: Towards a field-internal conceptualization in bilingual and second language education. International Journal of Bilingual Education \& Bilingualism, 7(2), 172-188. https://doi.org/10.1080/13670059908667693

Morgan, B. (2009). Transformative practitioners for critical EAP: Possibilities and challenges. Journal of English for Academic Purposes, 8(2), 86-99. https://doi.org/10.1016/j.jeap.2008.09.002

Nagamine, T. (2012). A metaphor analysis of preservice EFL teachers' beliefs regarding professional identity. The Asian EFL Journal Quarterly: Special Issue on Teacher Education, Identity and Development, 14(2), $141-171$. https://doi.org/10.1080/10476210309388

Nguyen, H. (2013). Peer mentoring: A way forward for supporting preservice EFL teachers psychosocially during the practicum. Australian Journal of Teacher Education, 38(7), 31- 44. https://doi.org/10.14221/ajte.2013v38n8.3

Nokes, J., Bullough, R., Egan, W., Birrell, J., \& Hansen, J. (2008). The paired-placement of student teachers: An alternative to traditional placements in secondary schools. Teaching and Teacher Education, 24(8), $2168-2177$.

Norlander-Case, K., Reagan, T., \& Case, C. (1999). The professional teacher: The preparation and nurturance of the reflective practitioner. San Francisco: Joessey-Bass. https://doi.org/10.1016/j.tate.2007.08.006

Olsen, B. (2008). Introducing teacher identity and this volume. Teacher Education Quarterly, 35(3), 3-6. https://doi.org/10.1080/08878730009555229

Piaget, J. (1970). Science of education and the psychology of the child. Trans. D. Coltman. New York: Orion Press

Rodgers, C., \& Scott, K. (2008). The development of the personal self and professional identity in learning to teach. New York: Routledge.

Ruhanen, L., Robinson, R., \& Breakey, N. (2013). A tourism immersion Practicum: Student expectations, experiences and satisfaction. Journal of Hospitality, Leisure, Sport \& Tourism Education, 13, 60-69. 
https://doi.org/10.3794/johlste.21.23

Ruohotie-Lyhty M. (2013). Struggling for a professional identity: Two newly qualified language teachers' identity narratives during the first years at work. Teaching and Teacher Education, 30, 120-129. https://doi.org/10.1016/j.tate.2004.11.001

Ryan G., Toohey S., \& Hughes C. (1996). The purpose, value and structure of the practicum in higher education: a literature review. Higher Education, 31, 355-377. https://doi.org/10.1111/j.2150-1092.1996.tb00189.x

Sachs, J. (2005). Teacher education and the development of professional identity: Learning to be a teacher. In P. Denicolo \& M. Kompf (Eds.), Connecting Policy and Practice: Challenges for Teaching and Learning in Schools and Universities (pp. 5-21). Oxford: Routledge. https://doi.org/10.1007/978-3-319-56499-9_1

Santoro, N. (1997). The construction of teacher identity: An analysis of school practicum discourse. Asia-Pacific Journal of Teacher Education, 25(1), 91-99. https://doi.org/10.1177/002248715300400207

Schulz, R. (2005). The practicum: More than practice. Canadian Journal of Education/Revue canadienne de l'éducation, 28(1), 147-167. https://doi.org/10.1037/h0084118

Sfard, A., \& Prusak, A. (2005). Telling identities: In search of an analytic tool for investigating learning as a culturally shaped activity. Educational Researcher, 34(4), 14-22. https://doi.org/10.3102/0013189x034001037

Singh, G., \& Richards, J. (2006). Teaching and learning in the language teacher education course room: A critical sociocultural perspective. RELC Journal, 37(2), 149-175. https://doi.org/10.1177/0033688206067504

Smagorinsky, P., Cook, L., Moore, C., Jackson, A., \& Fry, P. (2004). Tensions in learning to teach: Accommodation and the development of a teaching identity. Journal of Teacher Education, 55, 8-24. https://doi.org/10.1177/002248710405500509

Snyder, M. (2016). Advancing clinical education through an evidence-based practicum for psychiatric mental health APNs. Journal of the American Psychiatric Nurses Association, 22(3), 260. https://doi.org/10.1177/107839030401000601

Søreide, G. (2006). Narrative construction of teacher identity: Positioning and negotiation. Teachers and Teaching: Theory and Practice, 12(5), 527-547. https://doi.org/10.1080/1354060970030211

Strandell-Laine, C., Stolt, M., Leino-Kilpi, H., \& Saarikoski, M. (2015). Use of mobile devices in nursing student-nurse teacher cooperation during the clinical practicum: An integrative review. Nurse Education Today, 35(3), 493-499. https://doi.org/10.1016/0260-6917(89)90002-6

Sutherland L., Scanlon L., \& Sperring A. (2005). New directions in preparing professionals: Examining issues in engaging students in communities of practice through a school-university partnership. Teaching and Teacher Education, 21, 79-92. https://doi.org/10.1016/j.tate.2004.11.001

Tan, Y. (2005). Using community service projects to teach leadership and team-building: Theoretical foundations, students' reactions and practical considerations. Human resource development in Asia: Innovation, integration, globalization: Papers presented at the 4th Asian Conference of the Academy of HRD, Taipei, Taiwan, December 3-6, 551-557.

Van Huizen, P., Van Oers, B., \& Wubbels, T. (2005). A Vygotskian perspective on teacher education. Journal of Curriculum Studies, 37(3), 267-290. https://doi.org/10.1080/0022027830150209

van Veen, K., \& Sleegers, P. (2006). How does it feel? Teachers' emotions in a context of change. Journal of Curriculum Studies, 38(1), 85-111. https://doi.org/10.1080/0022027680010101

Varghese, M. (2006). Bilingual teachers-in-the-making in Urbantown. Journal of Multilingual and Multicultural Development, 27(3), 211-224. https://doi.org/10.1080/01434632.1982.9994081

Varghese, M., \& Johnston, B. (2007). Evangelical Christians and English language teaching. TESOL Quarterly, 4l(1), 5-31. https://doi.org/10.1002/j.1545-7249.1981.tb00365.x

Varghese, M., Morgan, B., Johnston, B., \& Johnson, K. A. (2005). Theorizing language teacher identity: Three perspectives and beyond. Journal of Language Identity \& Education, 4(1), 21-44. https://doi.org/10.1207/s15327701jlie0403_1

Walkington J. (2005). Becoming a teacher: Encouraging development of teacher identity through reflective practice. Asia-Pacific Journal of Teacher Education, 33(1), 53-64. https://doi.org/10.1177/002248718203300401 
Wenger, E. (1998). Communities of practice: Learning, meaning, and identity. UK: Cambridge University Press.

Wenger, E. (2000). Communities of practice and social learning systems. Organization, 7(2), 225-246. https://doi.org/10.1177/135050840072002

Wright, N. (2010). Twittering in teacher education: Reflecting on practicum experiences. Open Learning, 25(3), 259-265. https://doi.org/10.1080/02680513.2010.511936

$\mathrm{Xu}, \mathrm{H}$. (2012). Imagined community falling apart: A case study on the transformation of professional identities of novice ESOL teachers in China. TESOL Quarterly, 46(3), 568-578. https://doi.org/10.2307/3586047

$\mathrm{Xu}, \mathrm{H}$. (2013). From the imagined to the practiced: A case study on novice EFL teachers' professional change in China. Teaching and Teacher Education, 31, 79-86. https://doi.org/10.1016/0742-051X(89)90018-8

Zembylas, M. (2003). Caring for teacher emotion: Reflections on teacher self development. Studies in Philosophy and Education, 22, 103-125. https://doi.org/10.1023/a:1021177225548

Zlotkowski, E. (Ed.). (1998). Successful service-learning programs: New models of excellence in higher education. Bolton, MA: Anker Publishing Company. 